\title{
Financial Distress, Tax Loss Carried Forward, Corporate Governance and Tax Avoidance
}

\author{
Mayang Sekar Pembayun Khamisan ${ }^{1}$, Silvy Christina ${ }^{2}$ \\ ${ }^{1,2}$ Trisakti School of Management, Kyai Tapa 20, 11440, Jakarta, Indonesia
}

\begin{abstract}
Objective - This study aims to obtain empirical evidence about the factors that influence tax avoidance. The independent variables tested in this research were financial distress, tax loss carried forward, institutional ownership, managerial ownership, audit committee, audit quality, firm size, and return on assets with e Cash Effective Tax Rate (CETR) used as a dependent variable in this study.

Methodology/Technique - The companies used in this study are manufacturing companies listed on the Indonesia Stock Exchange (IDX) with a research period of 2016-2018. The number of research samples used were 162 data. The method of sampling used purposive sampling and this research used multiple regression analyses to test the hypothesis. Findings - This research provides the result that financial distress, tax loss carried forward, institutional ownership, managerial ownership, audit committee, audit quality, firm size, and return on assets have no influence on tax avoidance.

Originality/value - The difference between this study and previous studies is that this study focuses on financial distress, tax loss carried forward and corporate governance.

Type of Paper: Empirical.

JEL Classification: M41, M49.

Keywords: Financial Distress, Tax Loss Carried Forward, Institutional Ownership, Managerial Ownership, Audit Committee, Audit Quality, Firm Size, Return on Assets, Cash Effective Tax Rate.

Reference to this paper should be made as follows: Khamisan, M.S.P; Christina, S. (2020). Financial Distress, Tax Loss Carried Forward, Corporate Governance and Tax Avoidance, Acc. Fin. Review, 5 (3): 87 - 94. https://doi.org/10.35609/afr.2020.5.3(1)
\end{abstract}

\section{Introduction}

Taxes are compulsory contributions imposed upon people (taxpayers) under the law which does not provide for direct compensation from tax (Resmi 2011). Tax takes the highest position on the state budget structure (state budget) because tax is the most potential source of state revenue. It shows that tax makes a large contribution to state revenues which can be used to finance government programs to improve people's prosperity and reduce social inequality.

\footnotetext{
* Paper info: Revised: September 10, 2020

Accepted: December 31, 2020

* Corresponding author: Mayang Sekar Pembayun Khamisan

E-mail: mayangsekar98@gmail.com

Affiliation: Accounting, Trisakti School of Management, Indonesia
} 
Since 1984, Indonesia has been using Self-Assessment System in the tax collection system, where taxpayers are trusted to calculate, pay, and report their own amount of tax payable under taxation laws. The application of the system is expected to increase taxpayer's willingness and compliance in carrying out their tax obligations. According to Dharma and Ardiana (2016), for the government, tax is a source of state revenues, but for the company tax is an expense that reduces the company's net profit, so the company will try to reduce its tax expenses. This gap causes the differences in interests between the government and companies that can encourage companies to control the amount of tax payments (Darmawan and Sukartha 2014).

One of the ways that can be done to control the amount of tax payments is through tax avoidance, which is part of tax planning. Tax avoidance is a legal act that does not violate taxation laws (Pohan 2013, 14). Tax avoidance is a minimisation strategy undertaken by taxpayers legally and in accordance with the provisions of tax laws using methods and techniques to take advantage of the weaknesses contained within the laws and regulations, to reduce the amount of tax actually paid (Pohan, 2013, 14). There are several issues raised in this study, including whether there is an influence of financial distress, tax loss carried forward, and corporate governance to tax avoidance. Therefore, this study aims to determine the influence of financial distress, tax loss carried forward, and corporate governance to tax avoidance.

\section{Literature Review}

\subsection{Agency Theory}

In agency theory, the parties involved are management (agent) and investor (principal). The principal has a reason to believe that the agent will always act on behalf of the principal's interests (Godfrey et al., 2010). This problem arising from agency theory is agency problem. According Charitou et al. (2016) agency conflicts are divided into two types: type I, which is the conflict between shareholders to the manager, where a manager would make policies that benefit themselves and did not consider the interests of shareholders. Type II agency conflict which is the conflict between the majority shareholders with minority shareholders. The majority shareholders of the company that own the rights to the majority shareholder will make policies that benefit themselves ignoring the interests of minority shareholders. The agency theory is divided into two viewpoints, which are positive agency theory and principal-agent research theory. Positive agency theory discusses the objective differences that restrict the behavior of self-interest satisfying behaviors by the agents. The principal-agent research theory discusses the possibilities which may occur in the relationship between employers and employees, lawyers and their clients, buyers and suppliers and other agency relationships. In this research, according to agency theory, it is explained that the tax authorities (the government) as the principal expect the maximum amount of tax revenue while the company management as an agent want to generate significant profits and expect minimum tax payments.

\subsection{Tax Avoidance}

Tax avoidance is a minimisation strategy undertaken by taxpayers legally and in accordance with the provisions of tax laws using methods and techniques to take advantage of the weaknesses contained within the laws and regulations, to reduce the amount of tax actually paid (Pohan, 2013). Tax avoidance behaviour by managers tends to decrease firm value, as investors assume that low profits will result in low stock returns. Santa and Rezende (2016) found that tax avoidance has a negative effect on firm value. Another study conducted by Chen et al. (2014) found that tax avoidance behaviour increases agency costs and reduces firm value. However, Chen, Kee, and Rasiah (2016) identified an indirect relationship between tax avoidance and market value as a proxy of firm value; whereas, Desai and Dharmapala (2009) found that tax avoidance activity by firms does not increase firm value. 
Pohan (2013) described tax avoidance as a strategy and technique done legally and safely by taxpayers because it does not violate taxation provisions. Tax avoidance is undertaken by utilizing various weaknesses that exist in taxation laws and regulations. Companies perform tax avoidance to reduce tax payables by doing legal act and do not violate taxation laws. These tax avoidance activities cause many risks for companies including punishment and bad reputation or the tarnishing of a company's image in the public arena (Kalbuana et al. 2017).

\subsection{Financial Distress and Tax Avoidance}

Financial distress is a financial condition in which the company is in a state of crisis or unhealthy, so the company has financial difficulties in paying off its obligations (Rani 2017). Companies that experience financial distress are forced to take risks to avoid tax in line with the need for higher availability of cash, so they will ignore the negative image that might result as a consequence of tax avoidance (Frank et al. (2009) in Putri and Chariri (2017)).

Ha1: Financial distress has positive influence on tax avoidance.

\subsection{Tax Loss Carried Forward and Tax Avoidance}

According to Law No. 36 of 2008 Article 6 paragraph (2) on Income Tax, when a company has suffered a loss in an accounting period, the company will be given remission in paying tax. Company loss can be compensated starting in the next tax year in a row for up to 5 (five) years. The government will compensate the reduction of the amount of tax paid in the following year so it can be used by the company to reduce the amount of tax paid (Putra et al. 2018).

Ha2: Tax loss carried forward has positive influence on tax avoidance.

\subsection{Institutional Ownership and Tax Avoidance}

Institutional investors are sophisticated, and hence are better able to manipulate stock market information to predict earnings, a condition that will affect the increase in a firm's value. According to the Agency Theory developed by Jensen \& Meckling (1976), agency relations arise when the executive officer delegates authority to an agent to provide a service. Differences in the interests of managers (agents) and shareholders (executive officers) may cause agency problems, which can lead to non-achievement of corporate objectives in increasing a firm's value. The percentage of shares owned by the institution may affect things such as the process of preparing financial statements, in which there is no possibility of the accrual in the interest of the management.

Ngadiman and Puspitasari (2014) in Faizah and Adhivinna (2017) explained that institutional ownership is the number of shares owned by government, financial institutions, legal entities, foreign institutions, pension funds, and other institutions. Shleifer and Vishney (1986) stated that institutional owners have an important role to supervise, discipline, monitor, and control managers. The amount of voting rights held by institutional owners can force managers to focus on their performance and not prioritize their own interests.

Ha3: Institutional ownership has negative influence on tax avoidance.

\subsection{Managerial Ownership and Tax Avoidance}

Managerial ownership refers to those who are actively participating in corporate decision making (Sunarsih and Oktaviani, 2016). Jensen and Meckling (1976) explained that the greater number of shares owned by management in a company will make management more active in meeting the interests of 
shareholders and themselves. Managerial ownership will make managers consider the company's sustainability so that it makes them aware of paying tax owed by the company (Fadhila et al. 2017).

Ha4: Managerial ownership has negative influence on tax avoidance.

\subsection{Audit Committee and Tax Avoidance}

Based on POJK No.55/POJK.04/2015 about the Formation and Guidelines for the Work Implementation of the Audit Committee. Audit committee is described as a committee formed by the board of commissioners to support in the implementation of its duties and functions. The supervisions conduct by audit committees in the process of preparing financial statements and supervisions of internal controls is believed to reduce tax avoidance action (Putri and Chariri 2017).

Ha5: Audit committee has positive influence on tax avoidance.

\subsection{Audit Quality and Tax Avoidance}

According to Mulyani et al. (2018), audit quality exists when the auditor conducts an audit of the company's financial statements and finds a violation in the client's accounting system and then reports it the audit report. Financial statements that have been audited by public accounting firm (KAP) The Big Four's auditors based on several references are considered to be of higher quality because they are believed to display the actual condition of the company, therefore the companies audited by The Big Four KAP are considered to have a lower level of fraud (Damayanti and Susanto 2015). According to recent literature, highquality auditors have less incentives to engage in corporate tax avoidance, as they would bear harmful consequences if tax authorities detect aggressive positions. They may incur loss of reputation and trust following the public disclosure of tax avoidance behavior. Public accounting firm (KAP) The Big Four consist of Price Waterhouse Cooper-PWC, Deloitte Touche Tohmatsu, KPMG, dan Ernst \& Young. Auditors from KAP who produce good audit quality will certainly force auditors to avoid lawsuits and fraud (Khairunisa et al. 2017).

Ha6: Audit quality has negative influence on tax avoidance.

\subsection{Firm Size and Tax Avoidance}

Firm size is a scale that describes the size of a company. The size of a company can be known through various factors, including total assets owned by the company, total revenue, average total assets, and average total income (Puspita and Febrianti 2017). The greater the total assets owned by the company, the greater the company's productivity which will later have an impact on increasing company profits and affect the amount of tax paid (Rani 2017). Large companies should try to optimize their way in which they deal with market risk and uncertainty to have a better chance of dealing with losses. Companies with larger assets tend to be better able to generate profits compared to companies with smaller assets (Dewinta and Setiawan, 2016). Thus, companies with large profits will have greater stability in their operation. Further, firm size (which is proxied by its total assets) is indicative of the development of the company, which in turn can impact the improvement of the company's market performance. A relatively larger market share is reflective of a firm's competitiveness.

Ha7: Firm size has positive influence on tax avoidance. 


\subsection{Return on Assets and Tax Avoidance}

Return on assets or profitability is one of the measurements used to determine the extent of the company's effectiveness in using all its resources (Puspita and Febrianti 2017). The higher value of return on assets, the higher profit obtained so the amount of income tax will also increase along with the increase in corporate profits. It will motivate the companies to take tax avoidance actions (Dewinta and Setiawan 2016).

Ha8: Return on assets has positive influence on tax avoidance.

\section{Research Methodology}

This research involves all manufacturing companies listed on the Indonesia Stock Exchange (IDX) for the 2016-2018 period. The sample used in this study is manufacturing companies listed on IDX during the 20152018 period. The sampling method used in this study is purposive sampling.

\subsection{Definition Operation}

Tax avoidance which is measured by using Cash Effective Tax Rate (CETR) is the amount of cash spent to pay taxes derived from profit before tax. Financial distress is measured with cash flow coverage ratio (operating cash flows divided by average total liabilities). Tax loss carried forward will be measured by dummy variable that will be given a value of 1 if at the beginning of year $t$ there is tax loss carried forward and will be given 0 if there is no tax loss carried forward at the beginning of year $t$. The corporate governance variable such as institutional ownership is measured by total shares owned by institutional investors divided by total outstanding shares. Managerial ownership is measured by total shares owned by managerial divided by total outstanding shares. Audit committee is measured by total audit committee in the company. Audit quality is a dummy variable. A value of 1 is given if the company is audited by public accounting firm (KAP) The Big Four and a value of 0 is given if the company is not audited by public accounting firm (KAP) The Big Four. Firm size is calculated using a natural logarithm of total assets. Return on assets is measured by earnings after tax divided by total assets.

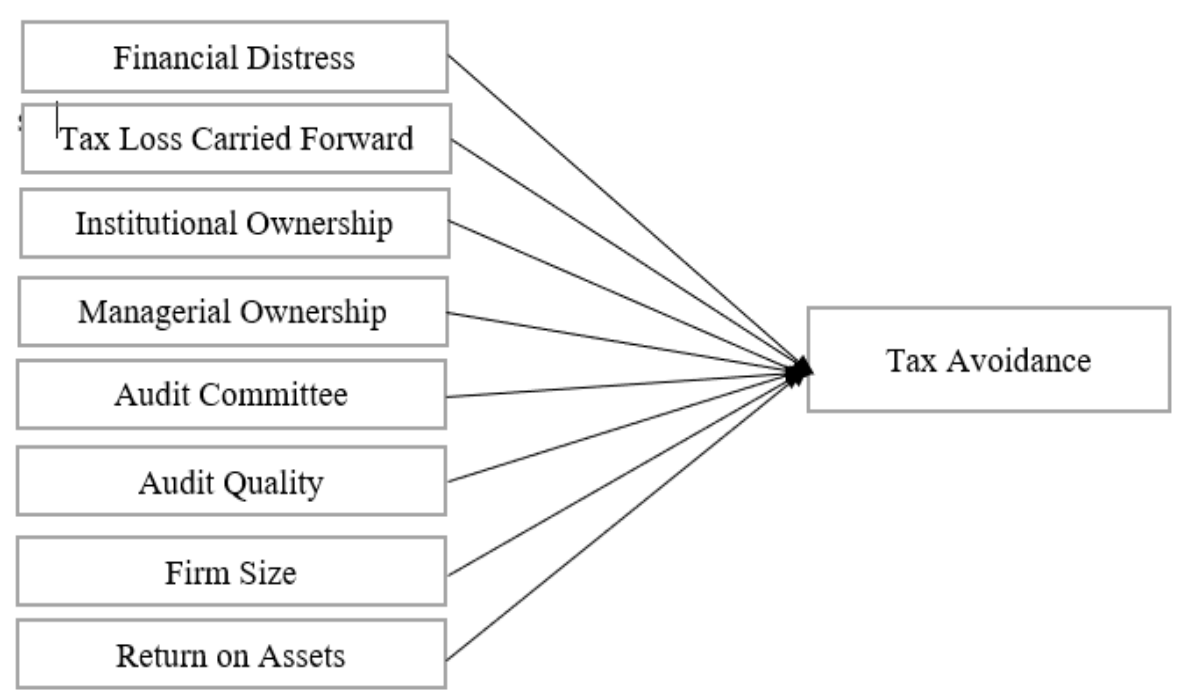

Figure 1. Research Framework 


\section{Results}

The result of descriptive statistic and hypothesis result is shown below:

Table 1. Descriptive Statistic

\begin{tabular}{llllll}
\hline Variable & $\mathrm{N}$ & Minimum & Maximum & Mean & $\begin{array}{l}\text { Std. } \\
\text { Deviation }\end{array}$ \\
\hline CETR & 162 & 0,044271 & 0,723842 & 0,279119 & 0,128112 \\
FD & 162 & $-0,160029$ & 1,992230 & 0,356321 & 0,402513 \\
TLCF & 162 & 0 & 1 & 0,23 & 0,421 \\
IO & 162 & 0,051432 & 0,994297 & 0,702464 & 0,195148 \\
MO & 162 & 0 & 0,380094 & 0,043485 & 0,094919 \\
AC & 162 & 1 & 5 & 3,09 & 0,399 \\
AQ & 162 & 0 & 1 & 0,45 & 0,499 \\
SIZE & 162 & 25,795711 & 33,473728 & 28,839451 & 1,591123 \\
ROA & 162 & 0,009007 & 0,526704 & 0,09211 & 0,087999 \\
\hline
\end{tabular}

Table 2. Hypothesis Results

\begin{tabular}{lll}
\hline Variable & B & Sig. \\
\hline (Constant) & 0,126 & 0,622 \\
FD & $-0,040$ & 0,228 \\
TLCF & $-0,021$ & 0,427 \\
IO & $-0,087$ & 0,244 \\
MO & $-0,073$ & 0,638 \\
AC & $-0,023$ & 0,402 \\
AQ & $-0,043$ & 0,111 \\
SIZE & 0,011 & 0,178 \\
ROA & $-0,037$ & 0,820 \\
\hline F- Test & & 0,225 \\
\hline R & & 0,256 \\
\hline Adjusted R2 & 0,017 \\
\hline
\end{tabular}

\section{Discussion}

Based on result of the research, it can be concluded that financial distress, tax loss carried forward, and corporate governance have no influence on tax avoidance. Financial distress does not have effect on tax avoidance. Companies that are facing financial distress will always suffer losses so the need for tax avoidance will be reduced, because the companies that suffer losses will be free from income tax expense and get loss compensation facility in the future. Tax loss carried forward does not have effect on tax avoidance. Tax loss carried forward is not something that is determined by the company in doing tax avoidance, but facilities that can be used by corporate taxpayers. Good Corporate Governance does not guarantee that the company is not involved in tax avoidance.

Institutional owners trust the board of commissioners to supervise and manage the company. Presence or absence of the institutional owner does not guarantee that the company is not doing tax avoidance. Managerial ownership does not affect tax avoidance because the manager does not have sufficient rights in the company's decisions making process, so the manager does not have a large opportunity and authority in the company. The large number of audit committees tasked with overseeing the preparation of the company's 
financial statements cannot guarantee that the audit committee is able to prevent management from taking tax avoidance actions.

Companies audited by the Big Four Public Accounting Firms may indeed be more trusted by the tax authorities because they have a good reputation. However, as the company can provide more benefits and prosperity because it is audited by a public accounting firm that already has a good reputation, there is a possibility that the public accounting firm may be able to deter he company from maximizing profits by being involved in fraudulent activities. Both large and small companies will be pursued by the tax authorities if they violate tax law and regulation (Faizah and Adhivinna 2017). Supervision held by the tax authorities is not only for large companies, but small companies can also attract the attention of the tax authorities to follow the applicable tax provisions and be subject to tax in accordance with applicable regulations. The higher the company's efficiency, the more likely it is that the company will comply with its tax obligations, so there is no tax avoidance.

\section{Conclusion}

Based on result of the research that is discussed above, it can be concluded that financial distress, tax loss carried forward, and corporate governance have no influence on tax avoidance. This study has several limitations: first, the study period is relatively short, from 2016 to 2018. Second, this study only used 8 independent variables where there were no independent variables that have influence on tax avoidance, while there were other independent variables that might have influence on tax avoidance which is not included in this study. Suggestions are made for further research to extend the study period to more than 3 years. In addition, it is recommended that, in the future, researchers can replace or add other independent variables such as sales growth.

\section{References}

Damayanti, Fitri and Tridahus Susanto. (2015). The Effect of Audit Committee, Institutional Ownership, Firm Risk and Return on Assets to Tax Avoidance. Journal of Business and Management, vol. 5 no. 2, 187-206.

Darmawan, I Gede Hendy and I Made Sukartha. 2014. The Effect of Good Corporate Governance, Leverage, Return on Assets, and Firm Size to Tax Avoidance. Udayana University Accounting E-Journal, Vol.9, No. 1: 143-161.

Desai, M. A., \& Dharmapala, D. (2009). Corporate tax avoidance and firm value. The review of Economics and Statistics, 91(3), 537-546. https://doi.org/10.1162/rest.91.3.537

Dewinta, I. A. R., \& Setiawan, P. E. (2016). The influence of company size, company age, profitability, leverage, and sales growth on tax avoidance. E-Journal of Accounting at Udayana University, 14 (3), 1584-1613.

Dharma, I. (2016). Made Surya and Putu Agus Ardiana, 2016. The Influence of Leverage, Fixed Asset Intensity, Company Size, and Political Connection Against Tax Avoidance. Udayana University Accounting E-Journal, 15 (1), 584-613.

Fadhila, Noriska Sitty, Dudi Pratomo, and Siska Priyandani Yudowati. 2017. The Effect of Managerial Ownerhsip and Corporate Governance to Tax Avoidance. Udayana University Accounting E-Journal, Vol. 21, No. 3: 1803-1820.

Faizah, S. N., \& Adhivinna, V. V. (2017). The effect of return on assets, leverage, institutional ownership and corporate size on tax avoidance. Journal of Accounting, 5 (2), 136-145. DOI 10.24964/ja.v5i2.288

Hanum, Hashemi Rodhian and Zulaikha. 2013. The Effect of Good Corporate Governance to Effective Tax Rate (BUMN Companies listed in Indonesia Stock Exchange). Diponegoro Journal of Accounting, Vol.2, No. 2: 1-10. Handayani, Y. D., \& Ibrani, E. Y. (2019). Corporate governance, share ownership structure and tax avoidance.

Idzni, I. N., \& Purwanto, A. (2017). The effect of foreign investor interest and institutional ownership on corporate tax avoidance. Diponegoro Journal of Accounting, 6 (1), 141-152.

Jensen, M. C., \& Meckling, W. H. (1976). Theory of the firm: Managerial behavior, agency costs and ownership structure. Journal of financial economics, 3(4), 305-360. https://doi.org/10.1016/0304-405X(76)90026-X

Kalbuana, N., Purwanti, T., \& Agustin, N. H. (2017). The Influence of Managerial Ownership, Deferred Tax Expenses, and Effective Tax Rates on Tax Avoidance in Indonesia. MAGISTRA, 29 (100). 
Leite Santa, S. L., \& Rezende, A. J. (2016). Corporate tax avoidance and firm value: from Brazil. Revista Contemporânea de Contabilidade, 13(30).

Mulyani, S., Wijayanti, A., \& Masitoh, E. (2018). The Effect of Corporate Governance on Tax Avoidance (mining companies listed on the IDX). Journal of Accounting and Business Research Airlangga, 3 (1). http://dx.doi.org/10.31093/jraba.v3i1.91

Pohan, C. A. (2013). Tax Management, Tax Planning and Business Strategies. Jakarta: PT Gramedia Pustaka Utama.

Hanif, I. N., \& Ardiyanto, M. D. (2019). Analysis of The Effect of Tax Avoidation Practices on Company Value: Information Transparency as A Moderating Variables. Diponegoro Journal of Accounting, 8 (3).

Putra, P. D., Syah, D. H., \& Sriwedari, T. (2018). Tax avoidance: Evidence of as a proof of agency theory and tax planning. International Journal of Research \& Review, 5(9), 52-60.

Putri, Rani Alifianti Herdian and Anis Chariri. 2017. The Effect of Financial Distress dan Good Corporate Governance to Tax Avoidance at Manufacturing Companies in Indonesia. Diponegoro Journal of Accounting, Vol.6, No. 2: 1-11.

Rani, Puspita. 2017. The Effect of Firm Size, Financial Distress, and Corporate Governance to Tax Avoidance. Journal of Accounting and Finance, Vol. 6, No. 2.

Official, S. (2011). Taxation: Theory and Cases. Sixth Edition. Jakarta: Salemba Empat.

Shleifer, A., \& Vishny, R. W. (1986). Large shareholders and corporate control. Journal of political economy, 94(3, Part 1), 461-488. https://doi.org/10.1016/j.pacfin.2016.02.010

Sunarsih, U., \& Oktaviani, K. (2016). Good corporate governance in manufacturing companies tax avoidance. Etikonomi, 15(2), 194863. DOI: 10.15408/etk.v15i2.3541

Zhang, C., Cheong, K. C., \& Rasiah, R. (2017). Corporate tax avoidance and performance: Evidence from China's listed companies. Institutions and Economies, 61-83. 